\title{
Giving Everyone a Fish COVID-19 and the New Politics of Distribution
}

\author{
Christopher Webb \\ London School of Economics and Political Science
}

\begin{abstract}
In response to widescale job losses produced by the COVID-I9 pandemic, states have drastically expanded social protections, primarily through cash transfer programs. Drawing from James Ferguson's notion of distributional politics, this reflection analyzes the meaning of this rapid global expansion of the welfare state and the political opportunities it provides. Based on two seemingly disparate cases, South Africa and Canada, I suggest that these expansions provide valuable opportunities for rethinking existing approaches to livelihoods, labour and social protection. These interventions also provide political possibilities through which a more radically redistributive politics can be articulated. In both contexts, state responses have provoked new challenges, dialogues, and experiments in distribution at multiple scales, from the neighbourhood to the nation state. This reflection calls for deeper inquiry into the multiple meanings of cash transfers and the political openings they provide. Finally, it provides guiding questions for future anthropological inquiry into livelihoods and social protection.
\end{abstract}

Keywords: COVID-I9; politics; distribution; labour; social protection; livelihoods; Canada; South Africa; cash transfers

Résumé: Face aux pertes d'emplois massives provoquées par la pandémie de COVID-I9, les États ont considérablement étendu la protection sociale, principalement au moyen de programmes de transferts monétaires. S'inspirant de la notion de politique de distribution proposée par James Ferguson, cette réflexion analyse la signification de l'expansion rapide de l'État-providence à l'échelle mondiale. À partir de deux cas en apparence distincts, l'Afrique du Sud et le Canada, je suggère que cette expansion offre de précieuses opportunités pour repenser les approches des modes de subsistance, du travail et de la protection sociale. Ces interventions étatiques ouvrent également des perspectives qui permettent de mettre en avant des politiques plus 
radicalement redistributives. Dans les deux contextes, les réponses de l'État ont engendré de nouveaux défis et ont donné lieu à des dialogues et des expériences de distribution à de multiples échelles, allant du quartier à l'État-nation. Cette réflexion appelle à un examen plus approfondi des significations multiples des transferts monétaires et des perspectives politiques ouvertes par ceux-ci. Enfin, elle pose des questions visant à guider les futures études anthropologiques sur les modes de subsistance et la protection sociale.

Mots-clés: COVID-I9; politique; distribution; travail; protection sociale; modes de subsistance; Canada; Afrique du Sud; transferts monétaires

\section{Introduction}

Tn June 2020, the International Labour Organization revised its estimates on 1 the impact of the COVID-I9 pandemic on global labour markets, adding a further 95 million full-time job losses to the previous 305 million (ILO 2020a). The impact of the pandemic on people's livelihoods has been wrenching. Lockdowns have intensified women's care work burden, informal workers have been subjected to police violence and evictions, and the future of entire sectors remains uncertain. Policy responses by governments around the world have been wide-ranging, from significant investments in healthcare to wage subsidies to food aid and rent relief. Perhaps the most common response has been the widespread use of cash transfers.

By the end of May 2020, I90 countries had planned, introduced or adapted social protection measures in responses to COVID-I9, with cash transfers (CTs) being the most widely used category of interventions (Gentilini et al. 2020). Cash transfers accounted for half of all government interventions, which included conditional and unconditional transfers, once off payments, childcare support, and pensions. Program designs have varied significantly, from the U.S. CARES Act, which provided direct cash transfers to I2 million people, to programs in Egypt which involved transfers to workers in the construction, agriculture, and fishing industry (Jerving 2020). The size of these transfers has been significant - on average they amount to 25 percent of monthly GDP per capita,

with low income countries registering the most significant increases (Jerving 2020). What is even more remarkable about this rapid expansion of the welfare state on a global scale, is the fact that 57 percent of these cash transfer programs are entirely new programs, often planned and implemented in a matter of weeks (Gentilini et al. 2020). 
The use of cash transfers as a solution to economic and subsequent livelihood crises is not new, but the scale and speed of expansions is unprecedented. While the long-term effects of the pandemic remain unclear, it is likely that these programs will endure in some form. What form they take, how they are implemented, and the actors involved will determine the future of the welfare state on a global scale. These interventions are not merely policy interventions, but exercises in governmentality that, in turn, produce new political subjectivities, contestations, and forms of resistance. Drawing on James Ferguson's (2015) concept of distributional politics, I suggest that these welfarist responses to the pandemic provide a conjunctural moment for rethinking existing approaches to livelihoods, labour, and social protection. The value of Ferguson's concept for analyzing our current moment is that it was developed in a context, Southern Africa, in which millions lack access to stable work and rely on either state support or the wages of other household members - a condition that many now face due to the pandemic. The pandemic has made clear both the deep inequalities in our societies and the insufficiencies of existing forms of social protection. This has provoked new challenges, dialogues, and experiments in distribution at multiple scales, from the neighbourhood to the nation state, and, ultimately, questions about how this should be funded. These interventions also provide political possibilities through which a more radically redistributive politics can be imagined and implemented. There is an urgent need to further interrogate both the meaning of the global expansion of the welfare state and political possibilities it provides.

The pandemic has accelerated a broader conjunctural crisis, revealing capitalism's inability to sustain life on a global scale and the neoliberal erosion of state supports. This is evidenced by the disproportionate impact of the virus on poor and racialized communities in both the Global North and South. It is helpful then, without resorting to vague abstractions, to draw comparative insights on responses to the pandemic across multiple scales. Based in Canada, but engaged in ethnographic research on social protection in South Africa, I have been struck by similarities, as well as important differences, in the political responses to the expansion of welfare spending in both contexts. Based on an analysis of these seemingly disparate cases, I offer neither an exhaustive assessment of these policies nor their efficacy, but an attempt at understanding the implications for political mobilization and subjectivity within and beyond the pandemic. What this will look like remains an open question - transfers can fulfil technocratic policy ambitions or amplify redistributive claims on 
national wealth. As such, they point to an emergent but deeply contested politics involving critical questions about the role of the state, the nature and meaning of work and citizenship, and the constitution of livelihoods in what Denning (2010) has described as an era of wageless life. In short, these welfarist expansions provide both danger and opportunity, allowing for radical reconceptualizations of the social as well as violent exclusions from it.

\section{A New Politics of Distribution}

The rapid rollout of CTs during the pandemic has been made possible by the restructuring of welfare regimes over the last two decades and the establishment of transfer and digital payment infrastructure in countries across the Global South. What began as experiments in anti-poverty policy in Latin America (notably in Mexico and Brazil) have become a global phenomenon - by 20I4, II9 developing countries had at least one type of unconditional cash transfer program (World Bank 20I4). Many of these programs occur in contexts where welfare state structures were historically absent or limited to a subset of the population. They also coexist with a widespread crisis of urban and rural livelihoods characterized by exit from agrarian economies and the erosion of the quantity and quality of waged work (Ferguson and Li 20I8; Li 20IO). One of the largest of these schemes has been South Africa's social grant program, which reaches 33 percent of the population or 44 percent of all households proportionately the largest program of this kind in the world (Ferguson 2015).

Inspired by these new welfarist experiments, Ferguson's (2015) Give a Man A Fish: Reflections on the New Politics of Distribution calls attention to the new rationalities of poverty that underpin these programs. These are not merely pragmatic policies, in a context of widespread unemployment, but represent:

...new "rationalities" of poverty and social assistance that, I suggest, may be understood as harbingers of, and intellectual resources for an emergent politics. This is what I term a 'politics of distribution,' and it involves new ways of thinking about a range of things that includes labour, unemployment, the family, and the meaning of "social" payments.

For Ferguson, CTs provide an opening in the edifice of neoliberal policymaking, and opportunities to experiment with forms of distribution that can provoke new political mobilizations and new ways to think about poverty. Ferguson's distributive politics asks us to rethink livelihoods and social assistance in contexts where the prospects of stable wage labour are increasingly remote, 
livelihoods are diverse and defined by widespread practices of distribution (in the form of remittances and income sharing).

Historically, South Africa's welfare state was structured around a racialized social wage, which facilitated the social mobility of white workers. The de-racialization of these systems after the end of apartheid coincided with a growing crisis of unemployment, workplace restructuring, and the rise of temporary, insecure, and outsourced employment relations (Webster and Von Holdt 2005). Social protections like the Unemployment Insurance Fund (UIF), a contributory policy requiring employers to register workers, has failed to cover a growing sector of the workforce employed on a casual or temporary basis and in the informal sector - 45 percent of South African workers are not eligible for the UIF (Bassier et al. 2020). The expansion of social grants - cash transfers directed to parents/guardians, pensioners, and the disabled — have alleviated chronic poverty, although their low levels are aimed at subsidizing rather than replacing wage income (Webb and Vally 2020). As such, they remain structured around a European welfare state model, provided largely to women and the elderly while men are expected to support households through wage labour - even as this is a remote prospect for many.

The Canadian context is characterized by similar labour market shifts, particularly the rapid growth of low wage precarious work, albeit in a context of far more expansive social supports (PEPSO 2013). Built around the Standard Employment Relation model dominant in the postwar period, Canada's employment insurance (EI) system was significantly undermined by the growth of non-standard work since I970s (Fudge and Vosko 200I). Labour markets have become increasingly polarized with a diminishing core of workers covered by regulations, insurance, and union representation existing alongside a growing cohort of women and racialized workers lacking access to many of these same benefits. This has been accompanied by cuts to welfare and restrictions on access to EI (Peck 200I). In 1996, EI benefits were lowered, eligibility requirements tightened, and the benefit period shortened (Johnson and Mahon 2005). The number of unemployed Canadians eligible to collect employment insurance has declined steadily since the I950s (Finkel 2006). In 2018, only 33 percent of unemployed women and 38 percent of unemployed men received EI benefits in 2018 (Macdonald 2020). Federal child benefit supports have been in place since the 1980 os, but the impact of these has arguably been undermined by low wages and provincial cuts to social assistance (Finkel 2006). While many 
elements of the Canadian welfare state have remained intact, from health care to public education, there is a broad consensus that the neoliberal era has significantly weakened these structures.

There are, of course, significant divergences in the history of welfare state structures. But as both cases illustrate, social protection policies in both the North and in many parts of the South are based on employment models that were, as Standing (20II) has argued, an anomaly in the history of global capitalism. Global economic restructuring has rendered this vision of employment largely obsolete, as workplace stability in the North has eroded, and workers in the South have integrated into highly flexible production chains, often through informal or unregulated employment. As a result, social protection policies based on temporary exit from full-time jobs fail to reflect labour market realities. Globally, some 45 percent of the labour force area is characterized by the ILO (2020b) as "vulnerable," meaning it lacks formal work contracts, adequate social protection, and union representation. Increasingly, people's incomes are derived not from a single waged job, but a bricolage of activities involving multiple part time jobs, self-employment, hustling, and dependence on others. These distributive arrangements are dominant in, but not confined to, the Global South (Gibson-Graham 2008).

\section{Social Protection and the Pandemic}

In both cases we see social protection models characterized by significant exclusions, reflecting employment models from a bygone era with levels of support wholly insufficient in the face of debilitating income shocks. The response by both states was to rapidly address these gaps by bolstering existing systems and rolling out new forms of income support.

In May 2020, the South African government announced a significant package of social and economic measures, including the expansion of existing grants, the creation of a new COVID-I9 grant, and the rollout of emergency food parcels. The income support package was aimed at supporting households that were not eligible for supports through UIF, even as some of the eligibility requirements had been relaxed. From the outset, the state struggled to implement these new policies. The expansion of the child social grant generated controversy, as the state chose to make payments per caregiver rather than per child. The COVID-I9 grant was beset by logistical and technical delays; of the 7 million who applied, only 600,000 had been paid by early June 2020, with the government admitting that 60 percent of those who had been rejected were 
eligible (The Economist 2020). By July, an expanded UIF plan had failed to compensate millions of workers for wages lost in the previous two months (Seekings 2020). The outcome has been devastating economic insecurity, with millions of jobs lost and increasing levels of poverty and hunger, which cleave to South Africa's racial divisions. Despite these shortcomings, surveys indicated widespread support for the expansion of social grants and the creation of new income supports in the form of a basic income (UJ/HSRC 2020).

In Canada, the government's pandemic response package included wage subsidies, tax deferrals, and income support. The Canada Emergency Response Benefit (CERB), a transfer program providing $\$ 2000$ per month for a maximum of four months, was introduced to support those who had lost their jobs or opted to remain home to care for someone. More than 8 million Canadians applied for CERB by June 2020, and the benefit was subsequently extended beyond the four-month period. The program was designed as a temporary and flexible response to the crisis intended to cover those who were ineligible for EI. In May, a reduced benefit was extended to students who could not find employment or who were unable to work due to the pandemic. These efforts have partially offset the most devastating impacts of the crisis, although some 2 million jobs had already been lost by April, rental evictions have spiked, and women's labour force participation reached its lowest point in three decades (Deschamps 2020; Gibson 2020; Statistics Canada 2020). The CERB program was initially criticized for its eligibility requirements - the already unemployed, part-time, self-employed, gig workers, and those who had exhausted their EI coverage were initially excluded (CCPA 2020). Despite this, one poll found that 86 percent of respondents approved of the program (Bricker 2020).

\section{Claims, Mobilizations, and Contestations}

Responses to the pandemic revealed the limitations of existing social protections, but they also provided grounds for a range of groups to make further claims on the state and criticize the insufficiencies of existing supports. First were calls to fix existing employment insurance systems. In Canada, unions noted that transitioning people from CERB to a modified EI system would exclude many from accessing support in a context of high unemployment (CLC 2020). In South Africa, trade union federations criticized the state for failing to implement an expanded UIF program, for not including coverage to workers over 60, and for not pursuing employers who were not contributing to the fund (COSATU 2020). 
Second were questions over who is included in pandemic support programs. South Africa's social grant program is paid out to South African citizens only; this is despite historically high rates of regional migration. During the lockdown, civil society groups successfully brought forward a case that government should extend the COVID-I9 grant to asylum seekers and those holding special permits - a move that was condemned by xenophobic and populist groups (Ellis 2020; SABC 2020). In Canada, CERB initially excluded international students and temporary foreign workers. After a public outcry, the benefit was amended in May to include these groups, provided they reside in Canada. A series of viral outbreaks in farming communities led migrant worker groups to push for improved protections and resident status. Migrant agricultural workers are frequently ineligible for EI payments after their contracts are over (MWAC 2020).

Third, the pandemic renewed calls for a basic income grant (BIG). Both countries have had BIG campaigns in the past, with Canada pioneering a number of experiments with basic income at various scales. In Canada, political parties, particularly the New Democratic Party through its \#Motion46, called for a BIG model in order to avoid exclusionary means testing, with advocates arguing that CERB should be transitioned to a BIG model (Mason 2020; NDP 2020). In South Africa, despite the challenges implementing the COVID grant, the government announced it would implement a basic income after October 2020, a move supported by a coalition of activists and civil society groups (Covid-I9 People's Coalition 2020; Shoki 2020). The \#PayTheGrants campaign highlighted the necessity of sustained income security in the form of a basic income in a context in which stable wage employment is not the norm for millions and is unlikely to become so (Dawson, Shaeera and Natasha 2020).

Fourth were public disputes over the morality of transfer payments and how recipients spent their money. The CERB program was dogged by accusations of fraud, with the government launching a hotline to report misuse of funds. Business claimed that the benefit was overly generous, causing labour shortages, particularly in low-wage retail and service sectors (Kelly and Guenette 2020). Newspapers ran articles suggesting that millennials were using CERB to indulge on "booze, drugs and Botox" (Kwong 2020). While the South African context is different (almost half the country receives some form of social grant support), expanded welfare supports have historically been hamstrung by the spectre of dependency (Barchiesi 20II). Transfers are seen as an ameliorative 
measure, with employment through economic growth seen as the primary tool to address poverty.

Fifth have been concerns over the gendered responsiveness of new supports. The pandemic laid bare inequities in caring labour and provided a rallying point for groups that have noted that adequate care supports must be part of the pandemic recovery for women (Kaplan and Roy 2020). In Canada, a high number of women left the labour market altogether to care for children and family (Scott 2020). In South Africa, child grants go overwhelmingly to women, with existing evidence suggesting that working-class women often use these grants to support multiple household members (Fakier and Cock 2009). The COVID-I9 grant is also the first grant to target unemployed, working-age men, and thus holds the potential to address gendered conflicts over the spending of child grants. There is also a growing body of evidence that transfers can have an impact on gender relations and women's empowerment (Granlund and Hochfeld 2020; Patel, Knijn and Van Wel 20I5).

Finally, were a range of responses to the insufficiencies of state support. As one South African activist put it, poor communities experienced the state not as a helping hand, but an empty seat (Shoki 2020). In South Africa, food parcels were delivered by religious groups, NGOs, and from the kitchens of working-class households. It is worth noting that many of these forms of non-market support had been present in the South long before the pandemic and underpin how the poor cope and survive within existing urban inequalities. As Bhan et al. (2020) have pointed out, in most of the global South it has been the neighbourhood rather than the state that has provided the most meaningful site of social protection and solidarity. In the North, these were termed mutual aid networks, evoking older forms of working-class solidarity, and often took the form of digital platforms aimed at providing support to the sick and elderly.

\section{Toward a Politics of the Rightful Share?}

These examples provide productive points of comparison between two rather distinct national contexts. They reveal how the pandemic amplified existing inequalities, exposed the limitations of existing social protection systems, raised questions about who should be eligible for support, and provided the grounds for political claims. Do these provide the potential for a new form of distributive politics, and what might this look like? 
As Ferguson $(2015,194)$ reminds us, what is important about cash transfers is not just the policy itself, but the way in which it "provides grounds for justifying redistributive claims." Both CERB and South Africa's social grant increases provided opportunities for a range of groups to highlight the limitations of existing supports and call for structural changes. These calls suggest that this sudden expansion of welfare provides multiple possibilities for new engagements and mobilizations that address the historic exclusions of these models (around gender and citizenship, for example), counter the myth of dependency, and seek to address the growing concentration of wealth. For example, the growing concentration of wealth in both countries, which has accelerated during the pandemic, has revived discussions over a wealth tax. For Ferguson $(2015,57)$, these claims and contestations around welfare policy advance a "politics of the rightful share," or a progressive politics based on a right to a "universal share in socially produced wealth."

Conjunctural moments, as Stuart Hall (1980) reminds us, are ones of both possibility and danger. Proposals for a BIG, for example, draw support from both the left and right, with progressive forces advocating for more expansive social protections (including remuneration for unpaid gendered labour), while the right sees it as an opportunity to scale back existing welfare supports and promote entrepreneurialism. In both South Africa and Canada, it appears that welfarist expansions are seen by the state as temporary ameliorative measures, even as the long-run impact of the pandemic remains unclear. At the time of writing, Canada has announced the end of CERB, transitioning the unemployed back onto a patchwork EI model. In South Africa, the state has declared that the COVID grant and related grant increases would not be made permanent (Cronje 2020). Even as the pandemic has provided multiple opportunities to advance distributional politics, it has also faced swift counterattacks by the usual forces of capital and neoliberal austerity.

It is here that Ferguson's distributional politics reveals its limitations, and where Nilsen's (2020) recent critique is prescient. As important as transfers have been in alleviating poverty amidst ongoing livelihood shocks, they have done little to reduce inequality. Further, research suggests that rather than providing an alternative to financialized neoliberalism, they are frequently compatible with it (Torkelson 2020; Webb 2016). This is primarily because they have not challenged the power of capital or advanced the further decommodification of goods and services. As Esping-Anderson (1990) argued, welfare states have historically pushed back against the frontiers of capital through advancing 
decommodification - the result of long waves of worker organizing and mobilization. A politics of the rightful share worth its salt will need to advance decommodification on multiple fronts, with expanded social protections being but one of the frontiers to challenge capital.

Finally, the conjuncture raises important questions for anthropologists. Do expanded forms of social protection reconfigure social membership and identity? Do they provoke further redistributive claims on the state? In what ways do they challenge the stigma of dependency linked to previous welfarist interventions? Can social membership linked to cash transfers provide the grounds for a new distributive politics and how can this connect to existing campaigns over decommodification? Do cash transfers produce political quietism or provide a platform for organizing future demands? What technologies and infrastructures underpin these circuits of distribution and how are they governed? How do new transfer programs recognize workers who have never been registered under any insurance program?

It is vital for scholars not to treat the pandemic as yet another opportunity to gather data on marginality - the features of which are abundantly clear. Rather, I propose that critical anthropologists interested in questions of livelihoods, labour, and the future of the welfare state examine how poor communities, workers and their organizations responded to this dramatic expansion of welfare supports and the mobilizations and contestations that have emerged from it. Doing so may provide us with a better understanding of models of distribution and livelihoods at multiple scales and the political formations, identities, and demands that may emerge from this extraordinary moment.

\section{Christopher Webb,}

London School of Economics and Political Science, christopherwebbı23@gmail.com

\section{References}

Barchiesi, Franco. 20II. Precarious Liberation: Workers, the State and Contested Social Citizenship in South Africa. Albany: SUNY Press. 
Bassier, Ihsaan, Joshua Budlender, Murray Leibbran, Rocco Zizzamia, and Vimal Ranchhod. 2020. "South Africa Can-and Should-Top Up Child Support Grants to Avoid a Humanitarian Crisis." The Conversation. March 3I. Accessed July I2, 2020. https://theconversation.com/south-africa-can-and-should-top-up-childsupport-grants-to-avoid-a-humanitarian-crisis-I35222.

Bhan, Gautam, Teresa Caldiera, Keylly Gillespie, and Simone AbdouMaliq. 2020. "The Pandemic, Southern Urbanisms and Collective Life." Society and Space. August 3. Accessed August 20, 2020. https://www.societyandspace.org/articles/the-pandemicsouthern-urbanisms-and-collective-life.

Bricker, David. 2020. "Commentary: CERB Did Its Job, but Many Canadians Polled Say It's Time to Move On." Global News. July I6. Accessed August 3, 2020. https:// globalnews.ca/news/7181907/cerb-popularity-canada/.

CCPA. 2020. "Canadian Centre for Policy Alternatives: COVID-I9: A Third of Unemployed Canadians Will Receive Nothing From either EI or New CERB." Ottawa: CCPA. Accessed July 13, 2020. https://www.policyalternatives.ca/newsroom/news-releases/covid-I9-third-unemployed-canadians-will-receive-nothingeither-ei-or-new.

CLC. 2020. "Canadian Labour Congress: We Need EI Reform Now." CLC. July 9. Accessed August 2, 2020. https://canadianlabour.ca/campaigns/we-need-eireform-now/.

COSATU. 2020. "COSATU Statement on President Cyril Ramaphosa and the Cabinet's Response to the Rise in Covid-I9 Infections." COSATU. July I2. Accessed August 2, 2020. http://mediadon.co.za/2020/07/I2/cosatu-statement-on-president-cyrilramaphosa-and-the-cabinets-response-to-the-rise-in-covid-I9-infections/.

Covid-I9 People’s Coalition. 2020. "Coalition Statement: Guaranteed Income Security for All.” Accessed August 5, 2020. https://ci9peoplescoalition.org.za/coalitionstatement-guaranteed-income-security-for-all/.

Cronje, Jan. 2020. "Ramaphosa Extends Special Covid-I9 Grant." News 24. October I5. Accessed October I7, 2020. https://www.news24.com/fin24/economy/live-ramaphosapresents-economic-rescue-plan-to-parliament-2020I0I5.

Dawson, Hannah, Kalla Shaeera, and Vally Natasha. 2020. "Extending Covid Grant a Step towards Income Guarantees." Business Day. October II. Accessed October I5, 2020. https://www.businesslive.co.za/bd/opinion/2020-IO-II-extending-covidgrant-a-step-towards-income-guarantees/. 
Denning, Michael. 20I0. "Wageless Life." New Left Review 66 (Nov/Dec): 79-97. https:// doi.org/IO.I515/978311043720I-OII.

Deschamps, Tara. 2020. "Women's Participation in Labour Force Reaches Lowest Level in 3 Decades Due to COVID-I9: RBC." CBC News. July I6. Accessed July 2I, 2020. https:/www.cbc.ca/news/canada/toronto/women-employment-canada-covid-I9I.5652788.

Ellis, Estelle. 2020. "Special Permit Holders and Asylum Seekers in SA Must Get CovidI9 Grant, Court Orders." Daily Maverick. June I9. Accessed July 3, 2020. https:// www.dailymaverick.co.za/article/2020-06-I9-refugees-and-asylum-seekers-in-samust-get-covid-I9-grant-court-orders/.

Esping Andersen, Gøsta. 1990. The Three Worlds of Welfare Capitalism. Cambridge: Polity Press.

Fakier, Khayaat, and Jacklyn Cock. 2009. "A Gendered Analysis of the Crisis of Social Reproduction in Contemporary South Africa." International Feminist Journal of Politics II (3):353-37I. https://doi.org/I0.1080/I4616740903017679.

Ferguson, James. 2015. Give a Man a Fish: Reflections on the New Politics of Distribution. Durham, DC: Duke University Press.

Ferguson, James, and Tani Li. 20I8. "Beyond the "Proper Job:" Political-Economic Analysis after the Century of Labouring Man." Working Paper 5I (PLAAS, UWC).

Finkel, Alvin. 2006. Social Policy and Practice in Canada: A History. Waterloo, ON: Wilfred Laurier University Press.

Fudge, Judy, and Leah Vosko. 200r. "Gender, Segmentation and the Standard Employment Relationship in Canadian Labour Law, Legislation and Policy." Economic and Industrial Democracy 22 (2): 27I-3Io. https://doi.org/IO.II77/oI4383I XoI222005.

Gentilini, Ugo, Mohamed Almenfi, Ian Orton, and Pamela Dale. 2020. "Social Protection and Jobs Responses to COVID-I9: A Real-Time Review of Country Measures." Washington, DC: World Bank. Accessed July 5, 2020. https://openknowledge.world bank.org/handle/I0986/33635.

Gibson, Victoria. 2020. "More than 6,00o Ontario Tenants Could Face Eviction for Nonpayment of Rent during COVID-19, New Figures Show." Toronto Star. July 25. Accessed August IO, 2020. https://www.thestar.com/news/gta/2020/o7/25/morethan-60oo-ontario-tenants-could-face-eviction-for-nonpayment-of-rent-duringcovid-I9-new-figures-show.html. 
Gibson-Graham, J.K. 2008. "Diverse Economies: Performative Practices for Other Worlds." Progress in Human Geography 32 (5): 613-632. https://doi.org/Io.II77/ 030913250809082I.

Granlund, Stefan, and Tessa Hochfeld. 2020. "That Child Support Grant Gives Me Powers'-Exploring Social and Relational Aspects of Cash Transfers in South Africa in Times of Livelihood Change." The Journal of Development Studies 56 (6): I230-I244. https://doi.org/I0.I080/00220388.2019.I650I70.

Hall, Stuart. 1980. “Thatcherism: A New Stage?” Marxism Today 24 (2): 26-28.

ILO. 2020a. "As Jobs Crisis Deepens, ILO Warns of Uncertain and Incomplete Labour Market Recovery." Geneva: International Labour Organization. Accessed July 5 , 2020. https://www.ilo.org/global/about-the-ilo/newsroom/news/WCMS_749398/ lang-en/index.htm?shared_from=shr-tls.

- - 2020b. "Vulnerable Employment, Total. ILOSTAT Database." Geneva: International Labour Organization. Accessed August 7, 2020. https://data.worldbank.org/indicator/SL.EMP.VULN.ZS.

Jerving, Sara. 2020. "Cash Transfers Lead the Social Assistance Response to COVID-I9." Devex. April I4. Accessed July 6, 2020. https://www.devex.com/news/cash-transferslead-the-social-assistance-response-to-covid-19-96949.

Johnson, Robert, and Rianne Mahon. 2005. "NAFTA, the Redesign, and Rescaling of Canada's Welfare State.” Studies in Political Economy 76 (I): 7-30.

Kaplan, Sarah, and Mara Roy. 2020. "Care Services Are Key to Pandemic Recovery for Women.” Toronto Star. July 23. Accessed August 7, 2020. https://www.thestar.com/ opinion/contributors/2020/o7/23/care-services-are-to-key-to-pandemic-recoveryfor-women.html.

Kelly, Dan, and Jasmin Guenette. 2020. "Opinion: CERB Should Not Be More Attractive Than Going to Work." National Post. July 22. Accessed August 9, 2020. https:// financialpost.com/opinion/opinion-cerb-should-not-be-more-attractive-thangoing-to-work.

Kwong, Evelyn. 2020. “It's a Coping Mechanism': Stressed from the Pandemic, This Jobless 28-Year-Old is Relying on CERB but Can't Stop Impulse Buying. Can She Rein in Her Spending and Pay Down Her Debt?” Toronto Star. July 27. Accessed August 3, 2020. https://www.thestar.com/business/personal_finance/2020/07/27/ botox-pot-booze-this-28-year-old-spent-almost-half-of-her-cerb-in-a-single-weekwith-no-plans-to-settle-she-needs-to-pay-I6k-in-debt-and-wants-to-travel-again. html?utm_source=dlvr.it\&utm_medium $=$. 
Li, Tania Murray. 20I0. "To Make Live or Let Die? Rural Dispossession and the Protection of Surplus Populations." Antipode 4I: 66-93.

Macdonald, David. 2020. "COVID-I9 and the Canadian Workforce." Ottawa: CPPA. Accessed August 2I, 2020. https://www.policyalternatives.ca/sites/default/files/ uploads/publications/2020/03/CCPA\%2oReport_COVIDi9\%20and\%20the\%20 Canadian\%2oWorkforce.pdf.

Mason, Gregory. 2020. "Has COVID-I9 Mandated a Basic Income?" Canadian Dimension. Accessed July 6, 2020. https://canadiandimension.com/articles/view/has-covid-I9mandated-a-basic-income.

MWAC. 2020. "Unheeded Warnings: COVID-I9 and Migrant Workers in Canada." Toronto: Migrant Workers Alliance for Change. Accessed July 23, 2020. https:// migrantworkersalliance.org/wp-content/uploads/2020/o6/Unheeded-WarningsCOVIDi9-and-Migrant-Workers.pdf.

NDP. 2020. "Singh Calls for Direct Help for All Canadians, Proposes Fixes to CERB." New Democratic Party. Accessed August 4, 2020. https://www.ndp.ca/news/singhcalls-direct-help-all-canadians-proposes-fixes-cerb.

Nilsen, Alf Gunvald. 2020. “Give James Ferguson a Fish.” Development and Change. http:// doi.org/IO.IIII/dech.I26I8.

Patel, Leila, Trudie Knijn, and Frits Van Wel. 2015. "Child Support Grants in South Africa: A Pathway to Women's Empowerment and Child Well-being." Journal of Social Policy 44 (2): 377-397. https://doi.org/IO.IOI7/Soo472794I400o9I9P.

Peck, Jamie. 200I. Workfare States. New York: Guilford Publications.

PEPSO. 2013. "It's More than Poverty: Employment Precarity and Household WellBeing." McMaster University and United Way Toronto. Accessed July 6, 2020. https://www.unitedwaygt.org/document.doc?id=9I.

SABC. 2020. "ATM Sams Ruling Ordering Inclusion of Asylum Seekers in R350 COVIDI9 Relief Grant." SABC. June 20. Accessed August 7, 2020. https://www.sabcnews. com/sabcnews/atm-slams-ruling-ordering-inclusion-of-asylum-seekers-in-r350covid-I9-relief-grant/.

Scott, Katherine. 2020. "COVID-I9 Crisis Response Must Address Gender Faultlines." Ottawa: CCPA. Accessed August 8, 2020. http://behindthenumbers.ca/2020/03/20/ covid-I9-crisis-response-must-address-gender-faultlines/. 
Seekings, Jeremy. 2020. "Covid-I9: Ramaphosa's Plan Is Good, but the Budget Is Insufficient." Daily Maverick. April 23. Accessed June 6, 2020. https://www.dailymaverick.co.za/article/2020-04-23-covid-I9-ramaphosas-plan-is-good-but-thebudget-is-insufficient/.

Shoki, William. 2020. "To Fight Unemployment We Have to Fight Capitalism: An Interview with Siyabulela Mama, Ayanda Kota and Khokhoma Motsi." Africa Is A Country. July 7. Accessed August 8, 2020. https://africasacountry.com/2020/o7/ to-fight-unemployment-we-have-to-fight-capitalism.

Standing, Guy. 20II. The Precariat: The New Dangerous Class. London: Bloomsbury.

Statistics Canada. 2020. "COVID-I9 and Job Displacement.” Ottawa: Statistics Canada. Accessed August 2I, 2020. https://www.statcan.gc.ca/eng/covidi9.

The Economist. 2020. "Covid-I9 Has Throttled South Africa's Economy." The Economist. July I8. Accessed August I, 2020. https://www.economist.com/middle-east-andafrica/2020/07/I8/covid-I9-has-throttled-south-africas-economy.

Torkelson, Erin. 2020. "Collateral Damages: Cash Transfer and Debt Transfer in South Africa.” World Development I26 (IO47II). https://doi.org/Io.IoI6/j.worlddev. 20I9.IO47II.

UJ/HSRC. 2020. "UJ-HSRC Covid-I9 Democracy Survey Summary Findings.” Accessed August 20, 2020. http://www.hsrc.ac.za/uploads/pageContent/II849/UJ-HSRC\%2O Covid-19\%2oDemocracy\%20Survey\%20Summary\%2oFindings.pdf.

Webb, Christopher. 20I6. "Profiting from Poverty." Review of African Political Economy Blog. Accessed October I8, 2020. http://roape.net/2016/08/30/profiting-poverty-debtfinance-social-grants-south-africa/.

Webb, Christopher, and Natasha Vally. 2020. "South Africa Has Raised Social Grants: Why This Shouldn't Be A Stop-Gap Measure.” The Conversation. Accessed June I, 2020. https://theconversation.com/south-africa-has-raised-social-grants-why-thisshouldnt-be-a-stop-gap-measure-138023.

Webster, Edward, and Karl Von Holdt. 2005. Beyond the Apartheid Workplace: Studies in Transition. Pietermaritzburg: University of KwaZulu Natal Press.

World Bank. 20I4. The State of Social Safety Nets 20I4. Washington, DC: World Bank. 